\title{
Rare case of low-grade extranodal NK/T-cell lymphoma, nasal type, arising in the setting of chronic rhinosinusitis and harboring a novel $\mathrm{N}$-terminal KIT mutation
}

\author{
Kyle Devins ${ }^{1}$, Stephen J. Schuster ${ }^{2}$, Gabriel C. Caponetti ${ }^{1}$ and Agata M. Bogusz ${ }^{1,2^{*}}$ (1)
}

\begin{abstract}
Background: Extranodal NK/T-cell lymphoma, nasal type (ENKTCL-NT), is a rare aggressive subtype of non-Hodgkin lymphoma characterized by angioinvasion, angiodestruction, necrosis and strong association with Epstein-Barr virus (EBV). ENKTCL-NT occurs worldwide and is more prevalent in Asian and the Native American populations of Mexico, Central and South America. It represents approximately $10 \%$ of all peripheral T-cell lymphomas worldwide. The aim of this report is to present a rare case of ENKTCL-NT with an unusually indolent clinical course and low-grade histopathologic features.

Case presentation: A 71-year-old Asian woman with a long-standing history of seasonal rhinosinusitis presented with persistent nasal congestion, cough, and fever unresponsive to antihistamines and antibiotics. Histopathological evaluation of a polypoid nasal mass revealed an atypical infiltrate with predominantly small lymphoid cells that were CD2+, surface CD3-, cytoplasmic CD3+, CD5(dim)+, CD7(dim)+, cytotoxic markers (granzyme B and perforin)+, EBER+ and CD56-. The Ki-67 proliferative index was very low (<1\%). T-cell receptor gamma gene rearrangement studies were positive for a monoclonal rearrangement, and sequencing studies identified a novel KIT mutation (p. K167 M, c. 500 A > T). A diagnosis of low-grade ENKTCL-NT was rendered.

Conclusions: Our case of ENKTCL-NT is unusual due to (1) an indolent clinical course (2) low-grade histopathologic features including a low proliferative index (3) lack of CD56 expression and (4) a novel KIT mutation. This case raises awareness of the existence of a subset of cases of ENKTCL-NT that can potentially be misdiagnosed as a reactive process, particularly in patients with recurrent chronic rhinosinusitis.
\end{abstract}

Keywords: NK/T-cell lymphoma, Epstein-Barr virus, Indolent, Low-grade, KIT mutation

\section{Background}

Extranodal NK/T-cell lymphoma, nasal type (ENKTCLNT), is a distinct form of non-Hodgkin lymphoma (NHL) characterized by an aggressive clinical course and a strong association with Epstein-Barr virus (EBV) [1]. The disease is most common in Asians and the Native American populations of Mexico, Central America and South America, while occurrence in the United States

\footnotetext{
* Correspondence: Agata.Bogusz@upsh.upenn.edu

'Department of Pathology and Laboratory Medicine, Division of Hematopathology, Hospital of the University of Pennsylvania, 7.018 Gates Pavilion, 3400 Spruce Street, Philadelphia, PA 19104-4283, USA

${ }^{2}$ Lymphoma Program, Abramson Cancer Center, University of Pennsylvania, Philadelphia, PA 19104, USA
}

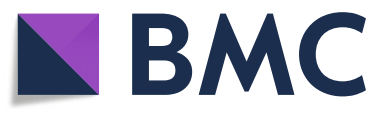

(c) The Author(s). 2018 Open Access This article is distributed under the terms of the Creative Commons Attribution 4.0 International License (http://creativecommons.org/licenses/by/4.0/), which permits unrestricted use, distribution, and reproduction in any medium, provided you give appropriate credit to the original author(s) and the source, provide a link to the Creative Commons license, and indicate if changes were made. The Creative Commons Public Domain Dedication waiver (http://creativecommons.org/publicdomain/zero/1.0/) applies to the data made available in this article, unless otherwise stated. age of patients ranges from 44 to 54 years, and it is more commonly seen in males [1]. Patients with nasal involvement typically present with a destructive sinonasal mass that can be accompanied by epistaxis [1]. Involvement of other body sites is less commonly observed, with cutaneous involvement being most frequent [1, 2]. EBV appears to be implicated in its pathogenesis, given that the lymphoma cells are almost invariably infected with the clonal episomal form of the virus [3-6]. The histopathologic features share an angiocentric and angiodestructive growth pattern regardless of anatomic location, with mucosal ulceration in the setting of nasal involvement 
[1]. The cytological spectrum of the lymphoma cells is broad and may include small to large cells, with or without anaplastic morphology. However, the majority of cases feature medium-sized cells or a mixture of small and larger cells with irregular nuclei, inconspicuous nucleoli and moderate amounts of often pale or clear cytoplasm with occasional azurophilic granules [1,7]. The lymphoma cells are occasionally accompanied by a variety of inflammatory cells, in which case the infiltrate can mimic a reactive process. The neoplastic cells are typically positive by in situ hybridization for EBV-encoded RNA (EBER) and by immunohistochemical staining for $\mathrm{CD} 2$, cytoplasmic CD3e, CD56 and cytotoxic markers such as perforin, granzyme B and TIA-1; immunohistochemical staining is usually negative for surface CD3 $[1,8]$. Although a variety of cytogenetic alterations have been described, with del(6)(q21q25) being the most frequently identified, none appear to be specific $[1,9]$. Recent genome-wide sequencing studies have provided an insight into the pathogenesis of ENKTCL-NT. Recurrent mutations in genes that encode proteins involved in the JAK/STAT, PI3K/AKT, NOTCH, PDGFR and KIT signaling pathways suggest that these may play a role in the pathogenesis of ENKTCL-NT and represent potential therapeutic targets $[1,9-12]$. The clinical course of the ENKTCL-NT is typically highly aggressive and historically it has been associated with poor survival rates $(30-40 \%)[1]$. Although recent advances in therapy, including upfront radiotherapy, have improved the outcomes [10-12], there is still a need for more effective treatments, particularly in advanced cases $[1,12,13]$.

In this report, we present a rare case of ENKTCL-NT with unusual clinicopathologic features akin to those seen in chronic rhinosinusitis and compare it with similar cases reported in the literature.

\section{Case presentation}

\section{Clinical findings}

A 71-year-old Asian woman presented for the evaluation of persistent nasal congestion, cough and fever. She was born in India but lived most of her life in the United States. Her past medical history was significant for seasonal allergic rhinosinusitis that was most severe in early summer. During the last recurrence, the symptoms of nasal congestion were unresponsive to antihistamines. Subsequently, she developed cough and low-grade fever and received two courses of oral prednisone and antibiotics for 6 weeks, without symptom resolution. A computer tomography $(\mathrm{CT})$ scan revealed mucosal thickening in the maxillary sinuses, bilaterally. Two months after the initial onset of symptoms, functional endoscopic sinus surgery was performed and a polypoid nasal mass was removed. Upon histopathological evaluation at an outside institution, a diagnosis of ENKTCL-NT was rendered.
Serological studies for EBV IgM were within normal limits, while EBV capsid IgG was elevated. Polymerase chain reaction (PCR) for EBV DNA performed on the patient's serum yielded results below the limit of detection for the assay. The patient subsequently transferred her care to our institution, and by then she had been completely asymptomatic for several weeks. A follow-up CT scan showed persistent mucosal thickening, and a repeat nasal biopsy was performed at our institution.

\section{Histology and immunohistochemistry}

The repeat nasal biopsy contained fragments of fibrotic sinonasal mucosa with a diffuse infiltrate (Fig. 1a and b) composed of atypical small to medium-sized lymphoid cells (Fig. 1b and c) with hyperchromatic, irregularly folded nuclei (Fig. 1d). The overlying sinonasal mucosa showed focal ulceration and although there was focal angiocentricity, no necrosis was observed. Immunohistochemical evaluation demonstrated that the atypical lymphoid cells were positive for cytoplasmic CD3 (Fig. 2a), CD2 (Fig. 2b), CD5 (Fig. 2c), granzyme B (Fig. 2d), perforin (Fig. 2e) and EBER (Fig. 2f). The Ki-67 proliferative rate was low ( $<1 \%$ overall) (Fig. $2 \mathrm{~g}$ ). The atypical cells were negative for CD56 (Fig. 2h), CD20 (Fig. 2i), CD4, CD7, CD8, TIA-1, CD30 and CD57.

\section{Flow cytometry}

Flow cytometric studies performed on tissue fragments from the nasal biopsy demonstrated a subset of lymphoid cells, comprising $6 \%$ of total events, with the following immunophenotype: CD2+, surface CD3-, CD4-, CD8-, CD5(dim)+, CD7(dim)+, CD16-, CD25-, CD56- and CD57- (Fig. 3). Also present were CD3+ T cells without significant loss of pan T-cell antigens and a CD4:CD8 ratio of 4:1 (53\% of total events) as well as few unremarkable CD3- CD7+ NK cells and polyclonal B-cells.

\section{T-cell receptor rearrangement studies}

T-cell receptor gamma gene rearrangement studies by PCR revealed a prominent 239 base pair peak in one reaction, and 192 and 193 base pair peaks in an irregular polyclonal distribution in a second reaction (Fig. 4).

\section{Gene sequencing studies}

Next-generation sequencing studies performed at the University of Pennsylvania using a custom, targeted sequencing amplicon panel for 68 hematologic malignancyassociated genes $[14,15]$ revealed a missense variant in exon 3 of the KIT gene at amino acid 167, converting the wild type residue lysine to methionine (p.K167 M, c. $500 \mathrm{~A}>\mathrm{T}$ ), with an allele frequency of $23 \%$. 


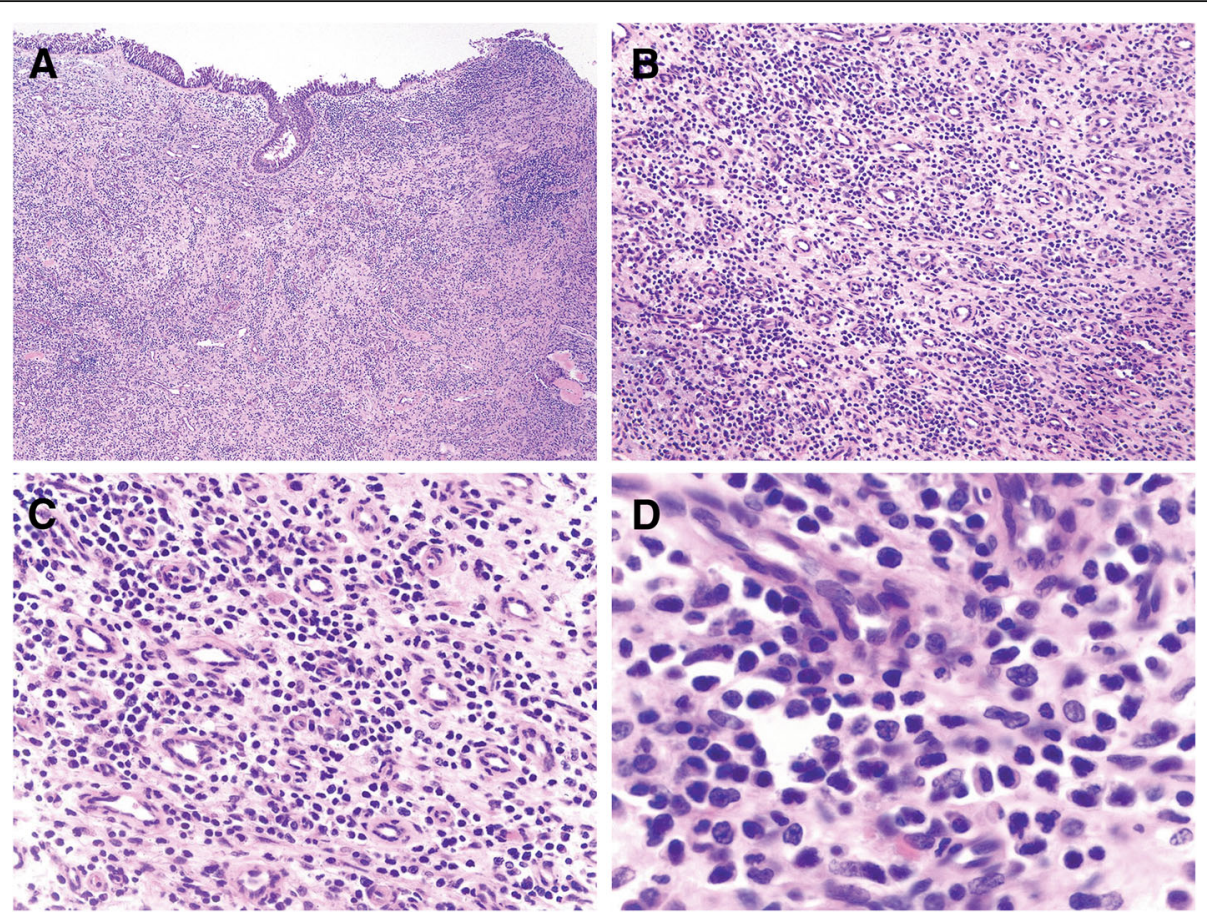

Fig. 1 Histological findings of the nasal biopsy. a H\&E-stained sections at low magnification (50x) demonstrate a diffuse infiltrate in the submucosa (H\&E). At higher magnification b 200x and c 400x), the majority of the cells are small to medium-sized and have irregular nuclei and inconspicuous nucleoli. d High magnification (1000x) highlights the irregular nuclear contours

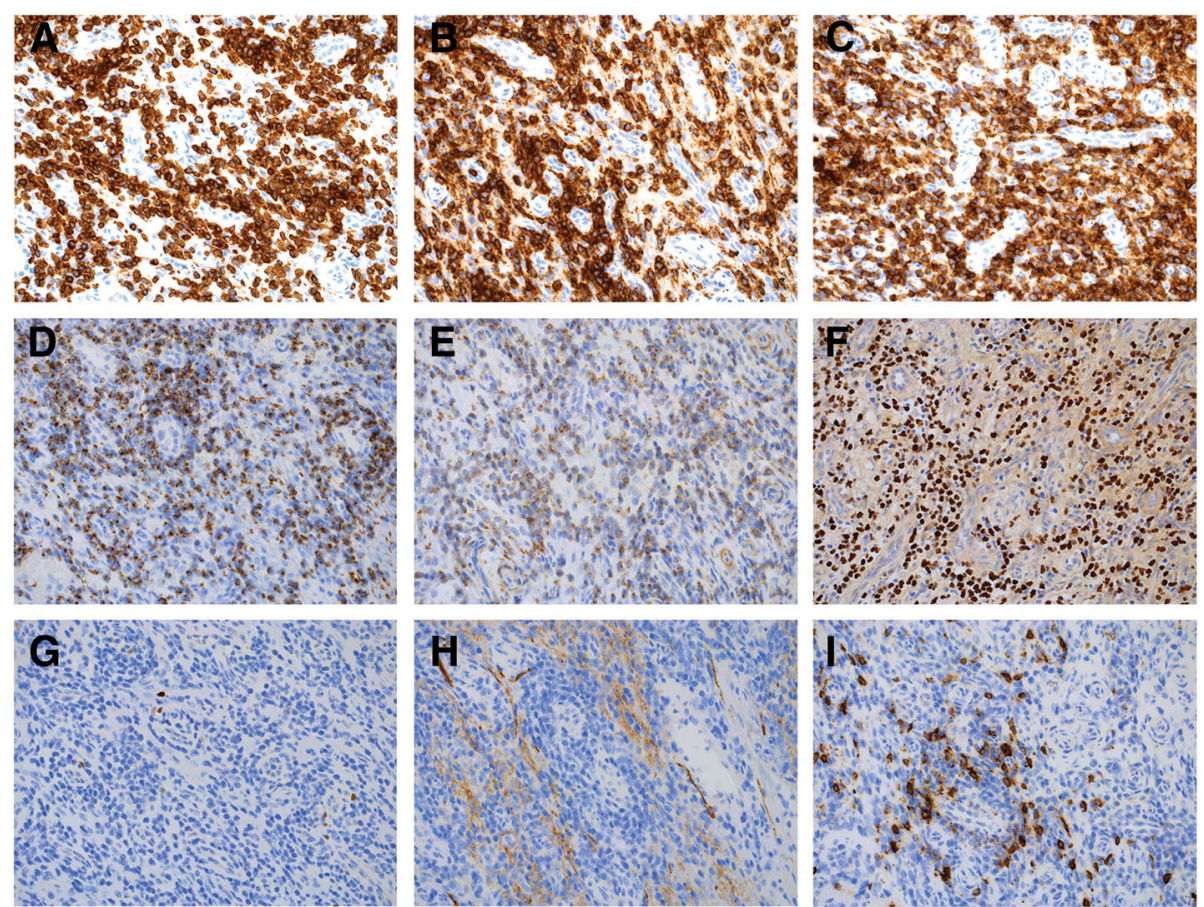

Fig. 2 Immunohistochemical findings of the nasal biopsy. a CD3 (200x) b CD2 (200x) c CD5 (200x) d granzyme B (200x) e perforin (200x) f EBER g Ki-67 h CD56 (200x) i CD20 (200x) 

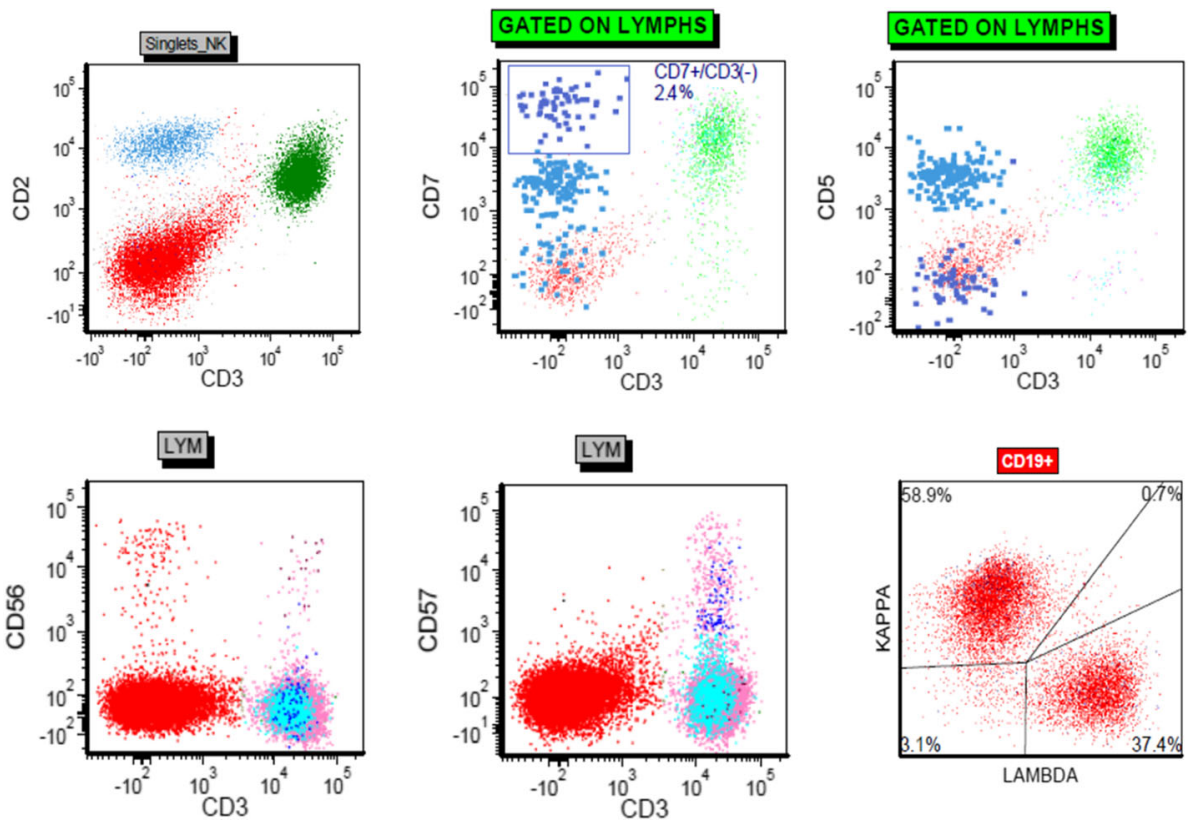

Fig. 3 Flow cytometric analysis of representative tissue from the nasal biopsy. The aberrant lymphoid population (light blue) is surface CD3-, CD2 ,+ CD5(dim)+, CD7(dim)+, CD56- and CD57- . Also present are normal CD3+ T cells (green) without significant loss of pan T-cell antigens (green) as well as normal CD3- and CD7+ NK cells (dark blue) and polyclonal B-cells (red)

\section{Discussion}

Clinically, indolent ENKTCL-NT appears to be an exceedingly rare entity as only seven other cases have been reported in the literature (Table 1). All previously reported cases demonstrated variably dense lymphocytic infiltrates without angioinvasion or necrosis [16-19]. Cytologic atypia, in the form of nuclear membrane irregularity, was present in only a few cases, and the findings often imitated reactive inflammatory infiltrates $[19,20]$. Although the number of cases described in the literature is low, the reported immunophenotypic results appear to show uniform expression of CD2, cytoplasmic CD3 and granzyme B and EBER, and variable expression of CD56. Five cases involved the sinonasal tract only, while two cases initially presented in the skin. Among the sinonasal cases with available clinical histories, low-grade ENKTCL-NT developed in patients with a long-standing history of chronic rhinosinusitis, often in association with nasal polyps $[17,18]$. In one report, a case of a CD20-positive ENKTCL-NT arose in a patient with a 10-year history of rhinorrhea and the lymphoma reportedly exhibited an indolent clinical course; however, this

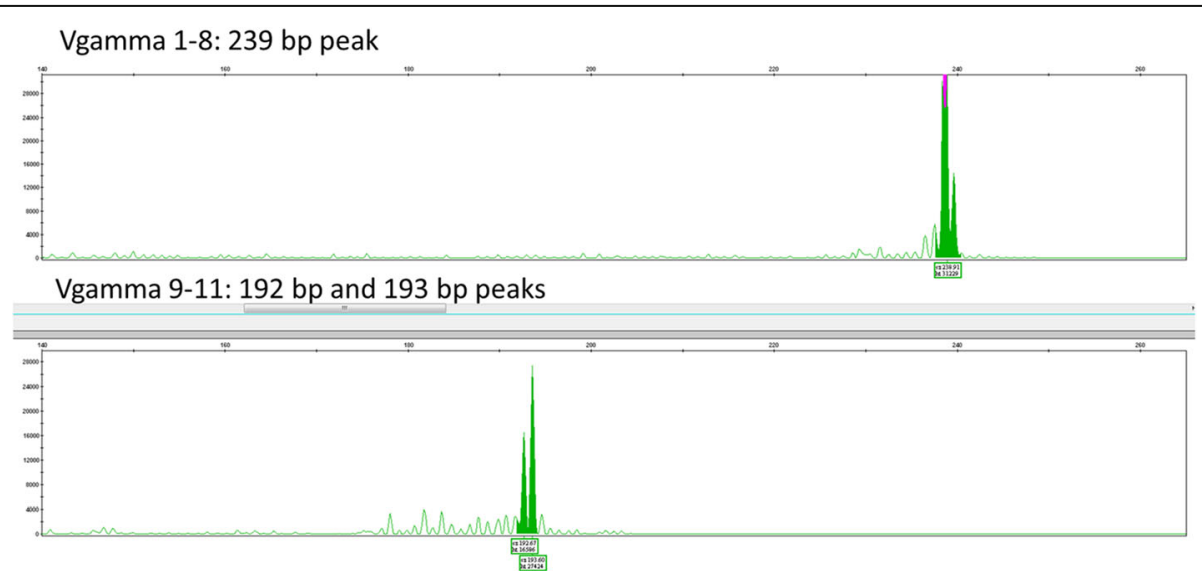

Fig. 4 T-cell receptor (TCR) gamma gene rearrangement studies by PCR performed on the nasal biopsy. The TCR gamma gene rearrangement studies revealed a monoclonal rearrangement with a 239 base pair peak in the V-gamma Reaction 1, and 192 and 193 base pair peaks in the Vgamma Reaction 2 


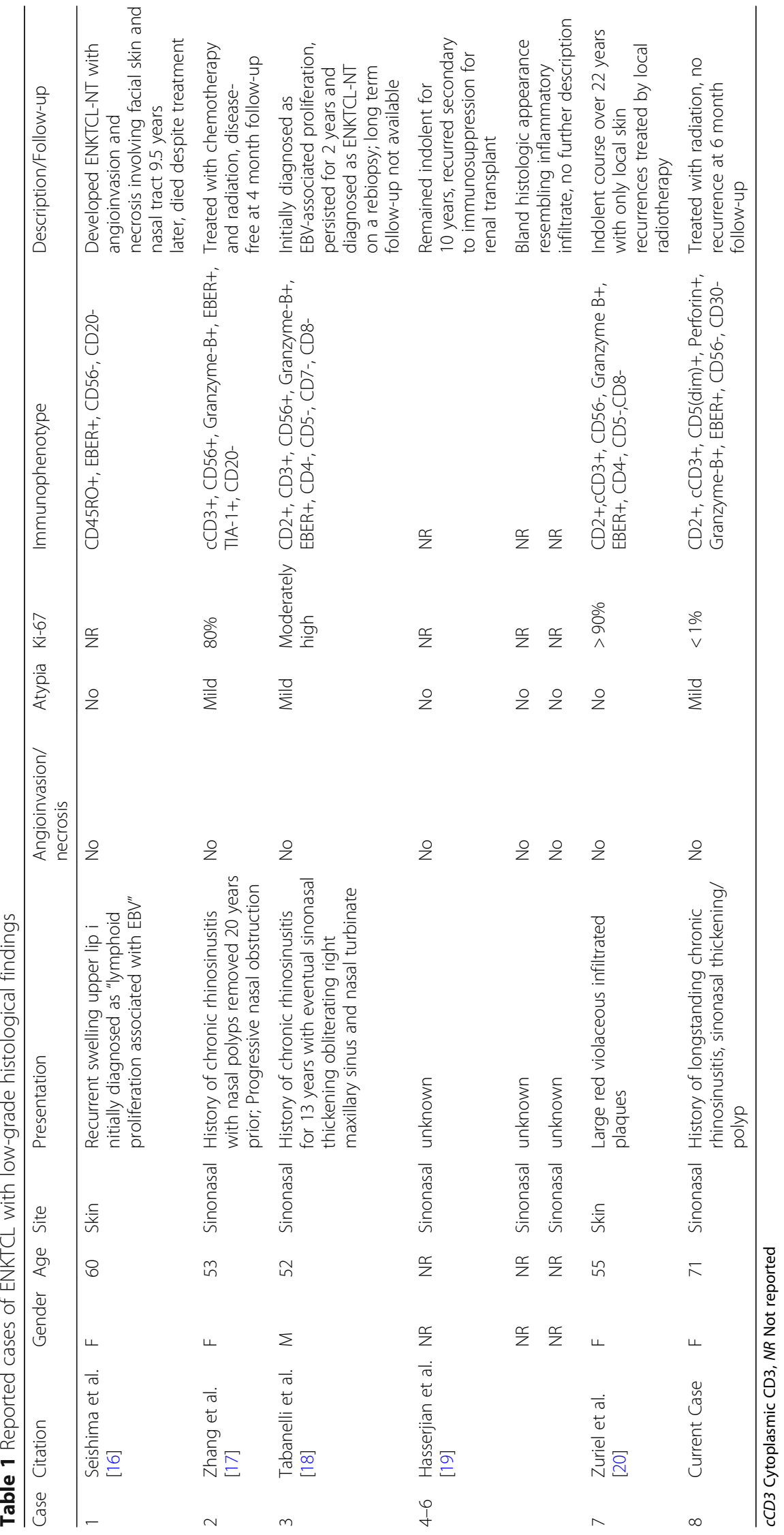


case showed aggressive morphologic features and the follow-up of 6 months was too short to confirm the clinical behavior of the neoplasm [21].

The Ki-67 proliferation index in our case was unusually low $(<1 \%)$ and this is, to the best of our knowledge, the lowest percentage of Ki67+ cells reported in ENKTCLNT. Low Ki-67 expression (defined as positive in $<65 \%$ of the lymphoma cells) has been shown to be predictive of a better prognosis in patients with stage I/II ENKTCL-NT [22]. The absence of CD56 expression seen in our case is another unusual feature in ENKTCL-NT with sinonasal location, although this was also seen in the two previously reported indolent cases with cutaneous involvement (Table 1) $[16,20]$.

Treatment with chemotherapy and/or radiation was administered in several of the reported cases, with a favorable clinical course after short-term follow-up, and one case demonstrated spontaneous remission without therapy [23]. The two indolent cases of ENKTCL-NT involving the skin were initially diagnosed as reactive inflammatory processes. $[16,20]$ While one of the latter cases had an indolent course over 22 years with only local skin recurrences [20], the other case recurred at 9.5 years with both nasal and cutaneous involvement, angioinvasion, necrosis, and an aggressive clinical course despite treatment [16]. In the report by Tabanelli et al [18], the authors document a case of low-grade ENKTCLNT that may have progressed from a polymorphic EBV-related NK/T-cell proliferation.

Although EBV appears to play a role in the development of ENKTCL-NT, the molecular pathogenesis of the disease has not been yet fully elucidated. Recurrent mutations, deletions and hypermethylation have been described in several genes, including KMT2D, ARID1A, TP53, KIT, JAK3, STAT3, STAT5B,CTNNB1, BCOR, ASXL3, EP300, DDX3X, ECSIT, KRAS, NRAS, PRDM1, BCL2L11 (BIM), DAPK1, PTPN6 (SHP1), TET2, SOCS6, and $A S N S[24,25]$. Interestingly, our case showed a previously unreported mutation in exon 3 of KIT with an allele frequency of $23 \%$, which strongly suggests that this is a somatic mutation. The proto-oncogene KIT encodes a receptor tyrosine kinase that plays an important role in many cellular processes including hematopoiesis, and therapeutic targeting of KIT signaling in cancer is an area of intense research [26]. Mutations of KIT are associated with several human malignancies, most notably gastrointestinal stromal tumors, acute myeloid leukemia, mastocytosis and melanoma. To date, little is known about the role of KIT mutations in the pathogenesis of ENKTCL-NT. Exon 11 or exon 17 KIT mutations have been identified in 10 to $71.4 \%$ of ENKTCL-NT cases from Asia [27]. The reported exon 11 and exon $17 \mathrm{mu}-$ tations comprise "hot spots" within the extracellular juxtamembrane domain and the activation loop of the kinase domain, respectively. However, a gain of function as a result of these KIT mutations has not been demonstrated [27]. The exon 3 mutation seen in our case (p. K167 M, c. $500 \mathrm{~A}>\mathrm{T}$ ) is located within the second Ig-like N-terminal domain of KIT, which is involved in ligand binding [25]. Identification of this novel KIT mutation might contribute to elucidating the pathogenesis of the indolent cases of ENKTCL-NT.

\section{Conclusions}

In summary, we present a unique case of indolent ENKTCL-NT with low-grade histopathologic features (including an extremely low proliferation index), unusual lack of CD56 expression, and a novel KIT mutation.

Our findings raise awareness of the existence of this apparently rare but likely underreported entity which can potentially be mistaken for a reactive process, and underlines the need for a thorough morphologic, immunohistochemical and molecular evaluation for its diagnosis.

\section{Abbreviations}

CT: Computer tomography; EBER: EBV-encoded RNA; EBV: Epstein-Barr virus; ENKTCL: Extranodal NK/T-cell lymphoma; ENKTCL-NT: Extranodal NK/T-cell lymphoma, nasal type; NHL: Non-Hodgkin lymphoma; PCR: Polymerase chain reaction

\section{Acknowledgements}

The authors thank the Center for Personalized Diagnostics of the University of Pennsylvania for performing of the sequencing analysis.

\section{Funding}

The authors received no financial support for this publication.

\section{Availability of data and materials}

The histological specimens and the corresponding data belong to the Department of Pathology and Dermatology of the University of Pennsylvania and are available upon request for review by the Editor-in-Chief.

\section{Authors' contributions}

$\mathrm{KD}, \mathrm{AMB}$ and $\mathrm{GCC}$ reviewed the case. KD and AMB wrote the manuscript. GCC and SJS edited the manuscript. All authors contributed to discussions and gave final approval of the submitted manuscript.

Ethics approval and consent to participate

Not applicable.

\section{Consent for publication}

Written informed consent for publication of their clinical details and/or clinical images was obtained from the patient. A copy of the consent form is available for review by the Editor of this journal.

\section{Competing interests}

The authors declare that they have no competing interests.

\section{Publisher's Note}

Springer Nature remains neutral with regard to jurisdictional claims in published maps and institutional affiliations.

Received: 17 September 2018 Accepted: 29 October 2018 Published online: 23 November 2018

\section{References}

1. Swerdlow SHCE, Harris NL, et al. WHO classification of tumours of haematopoietic and lymphoid tissues. Lyon: International Agency for Research on Cancer (revised 4th edition); 2016. 
2. Haverkos BM, Pan Z, Gru AA, Freud AG, Rabinovitch R, Xu-Welliver M, Otto B, Barrionuevo C, Baiocchi RA, Rochford R, Porcu P. Extranodal NK/T cell lymphoma, nasal type (ENKTL-NT): an update on epidemiology, clinical presentation, and natural history in north American and European cases. Curr Hematol Malig Rep. 2016;11(6):514-27. https://doi.org/10.1007/s11899-016-0355-9.

3. Arber DA, Weiss LM, Albujar PF, Chen YY, Jaffe ES. Nasal lymphomas in Peru. High incidence of T-cell immunophenotype and Epstein-Barr virus infection. Am J Surg Pathol. 1993;17(4):392-9.

4. Chan JK, Sin VC, Wong KF, Ng CS, Tsang WY, Chan CH, Cheung MM, Lau WH. Nonnasal lymphoma expressing the natural killer cell marker CD56: a clinicopathologic study of 49 cases of an uncommon aggressive neoplasm. Blood. 1997:89(12):4501-13

5. Chan JK, Yip TT, Tsang WY, Ng CS, Lau WH, Poon YF, Wong CC, Ma WW. Detection of Epstein-Barr viral RNA in malignant lymphomas of the upper aerodigestive tract. Am J Surg Pathol. 1994;18(9):938-46.

6. Kwong YL. Natural killer-cell malignancies: diagnosis and treatment. Leukemia. 2005:19(12):2186-94. https://doi.org/10.1038/sj.leu.2403955.

7. Quintanilla-Martinez L, Franklin JL, Guerrero I, Krenacs L, Naresh KN, RamaRao C, Bhatia K, Raffeld M, Magrath IT. Histological and immunophenotypic profile of nasal NKT cell lymphomas from Peru: high prevalence of p53 overexpression. Hum Pathol. 1999:30(7):849-55.

8. Kwong YL, Chan AC, Liang R, Chiang AK, Chim CS, Chan TK, Todd D, Ho FC. CD56+ NK lymphomas: clinicopathological features and prognosis. $\mathrm{Br} J$ Haematol. 1997;97(4):821-9.

9. Huang Y, de Leval L, Gaulard P. Molecular underpinning of extranodal NK/Tcell lymphoma. Best Pract Res Clin Haematol. 2013;26(1):57-74. https://doi. org/10.1016/j.beha.2013.04.006.

10. Suzuki R. Pathogenesis and treatment of extranodal natural killer/T-cell lymphoma. Semin Hematol. 2014;51(1):42-51. https://doi.org/10.1053/j. seminhematol.2013.11.007.

11. Suzuki R. NK/T cell lymphoma: updates in therapy. Curr Hematol Malig Rep. 2018;13(1):7-12. https://doi.org/10.1007/s11899-018-0430-5.

12. Yamaguchi M, Suzuki R, Oguchi M. Advances in the treatment of extranodal NK/T-cell lymphoma, nasal type. Blood. 2018;131(23):2528-40. https://doi. org/10.1182/blood-2017-12-791418. Epub 2018 Mar 30.

13. Tse E, Kwong YL. How I treat NK/T-cell lymphomas. Blood. 2013;121(25): 4997-5005. https://doi.org/10.1182/blood-2013-01-453233.

14. Sloan CE, Luskin MR, Boccuti AM, Sehgal AR, Zhao J, Daber RD, Morrissette JJ, Luger SM, Bagg A, Gimotty PA, Carroll M. A modified integrated genetic model for risk prediction in younger patients with acute myeloid leukemia. PLoS One. 2016;11(4):e0153016. https://doi.org/10.1371/journal.pone.0153016.

15. Patel JP, Gonen M, Figueroa ME, Fernandez H, Sun Z, Racevskis J, Van Vlierberghe P, Dolgalev I, Thomas S, Aminova O, Huberman K, Cheng J, Viale A, Socci ND, Heguy A, Cherry A, Vance G, Higgins RR, Ketterling RP, Gallagher RE, Litzow M, van den Brink MR, Lazarus HM, Rowe JM, Luger S, Ferrando A, Paietta E, Tallman MS, Melnick A, Abdel-Wahab O, Levine RL. Prognostic relevance of integrated genetic profiling in acute myeloid leukemia. N Engl J Med. 2012;366(12):1079-89. https://doi.org/10.1056/NEJMoa1112304.

16. Seishima M, Yuge M, Kosugi H, Nagasaka T. Extranodal NK/T-cell lymphoma, nasal type, possibly arising from chronic Epstein-Barr virus infection. Acta Derm Venereol. 2010;90(1):102-3. https://doi.org/10.2340/ 00015555-0778.

17. Zhang Qing-Fu HY-N, Li-Mei S, Ying T, Qiu X-S. Nasal extranodal NK/T-cell lymphoma mimicking inflammatory polyp: a case with indolent clinical behavior. Int J Clin Exp Pathol. 2016;9(1):336-40.

18. Tabanelli WR, Zanelli M, Righi S, Gazzola A, Mannu C, Pileri S, Sabattini E. A case of Sinonasal Extranodal NKTT-cell lymphoma with indolent behaviour and low-grade morphology. Case Rep Clin Med. 2014;3:596-600. https://doi. org/10.4236/crcm.2014.311129.

19. Hasserjian RP, Harris NL. NK-cell lymphomas and leukemias: a spectrum of tumors with variable manifestations and immunophenotype. Am J Clin Pathol. 2007;127(6):860-8. https://doi.org/10.1309/2F39NX1AL3L54WU8.

20. Zuriel D, Fink-Puches R, Cerroni L. A case of primary cutaneous extranodal natural killer/t-cell lymphoma, nasal type, with a 22-year indolent clinical course. Am J Dermatopathol. 2012;34(2):194-7. https://doi.org/10.1097/DAD. Ob013e318230ee41.

21. Jiang $Q P$, Liu SY, Yang YX, Tan XX, Peng J, Xiong ZT, Li Z. CD20-positive NK T-cell lymphoma with indolent clinical course: report of case and review of literature. Diagn Pathol. 2012;7:133. https://doi.org/10.1186/1746-1596-7-133.

22. Kim SJ, Kim BS, Choi CW, Choi J, Kim I, Lee YH, Kim JS. Ki-67 expression is predictive of prognosis in patients with stage I/II extranodal NK/T-cell lymphoma, nasal type. Ann Oncol. 2007;18(8):1382-7. https:/doi.org/10.1093/ annonc/mdm183.

23. Isobe Y, Aritaka N, Sasaki M, Oshimi K, Sugimoto K. Spontaneous regression of natural killer cell lymphoma. J Clin Pathol. 2009;62(7):647-50. https://doi. org/10.1136/jcp.2008.062976.

24. Huang Y, de Reynies A, de Leval L, Ghazi B, Martin-Garcia N, Travert M, Bosq J, Briere J, Petit B, Thomas E, Coppo P, Marafioti T, Emile JF, Delfau-Larue MH, Schmitt C, Gaulard P. Gene expression profiling identifies emerging oncogenic pathways operating in extranodal NKT-cell lymphoma, nasal type. Blood. 2010 115(6):1226-37. https://doi.org/10.1182/blood-2009-05-221275.

25. Lennartsson J, Jelacic T, Linnekin D, Shivakrupa R. Normal and oncogenic forms of the receptor tyrosine kinase kit. Stem Cells. 2005;23(1):16-43. https://doi.org/10.1634/stemcells.2004-0117.

26. Ashman LK, Griffith R. Therapeutic targeting of c-KT in cancer. Expert Opin Investig Drugs. 2013:22(1):103-15. https://doi.org/10.1517/13543784.2013.740010.

27. Hongyo T, Li T, Syaifudin M, Baskar R, Ikeda H, Kanakura Y, Aozasa K, Nomura T. Specific c-kit mutations in sinonasal natural killer/T-cell lymphoma in China and Japan. Cancer Res. 2000;60(9):2345-7.
Ready to submit your research? Choose BMC and benefit from:

- fast, convenient online submission

- thorough peer review by experienced researchers in your field

- rapid publication on acceptance

- support for research data, including large and complex data types

- gold Open Access which fosters wider collaboration and increased citations

- maximum visibility for your research: over $100 \mathrm{M}$ website views per year

At BMC, research is always in progress.

Learn more biomedcentral.com/submissions 